\title{
CIPATAT KOLOT: DINAMIKA KAMPUNG ADAT DI ERA MODERNISASI
}

\author{
CIPATAT KOLOT \\ DYNAMICS OF TRADITIONAL VILLAGE IN THE ERA OF MODERNIZATION
}

Irvan Setiawan

Balai Pelestarian Nilai Budaya (BPNB) Bandung

Jl. Cinambo no. 136 Ujungberung - Bandung 40294

e-mail: kamaliasetiawan@yahoo.co.id

\begin{abstract}
Abstrak
Kampung adat merupakan bagian dari aset budaya yang perlu dilestarikan. Rekapitulasi kampung adat di Provinsi Jawa Barat bersifat relatif karena masih ada beberapa kampung adat yang belum terdata, dan salah satunya adalah Kampung Cipatat Kolot di Desa Kiarapandak Kecamatan Sukajaya Kabupaten Bogor. Dinamika budaya akibat modernisasi membuat Kampung Cipatat Kolot menjadi sebuah kampung yang mengikuti perkembangan zaman. Aset budaya yang menjadi kunci sebuah kampung adat mulai luntur. Sementara itu, pendataan dan pengkajian mengenai Kampung Cipatat Kolot masih sangat minim. Penelitian ini mencoba untuk mengeksplorasi dan mengkaji aset dinamika budaya yang masih dimiliki Kampung Cipatat Kolot. Dengan menggunakan metode penelitian kualitatif, penelitian ini menyimpulkan bahwa sangat disayangkan apabila aset budaya Kampung Cipatat Kolot tidak dilestarikan, salah satunya karena makam Buyut Cipatat sebagai sesepuh dan menjadikan Kampung Cipatat Kolot menjadi sebuah kampung adat masih sangat dihormati tidak hanya oleh warga sekitar tetapi juga kasepuhan dalam kesatuan adat Banten Kidul. Selain itu dinamika budaya masih belum begitu jauh yang ditandai oleh masih adanya upacara tradisional yang biasa dilaksanakan oleh kampung adat dalam wilayah kesatuan Banten Kidul.
\end{abstract}

Kata kunci: Dinamika, Cipatat Kolot, Kampung adat.

Abstract

Traditional village as one of the cultural heritage should be conserved. The numbers of traditional village still in process of recapitulation. One of traditional village is Kampung Cipatat Kolot in Desa Kiarapandak Kecamatan Sukajaya Kabupaten Bogor. The village is not holding the traditional ways anymore; they live long with the modernization. The cultural asset vanished. Meanwhile, there's still lack of data and research about Cipatat Kolot village. This research tries to explore and examine the cultural heritage existence of Kampung Cipatat Kolot. Using qualitative method, the research concludes that the cultural assets of Kampung Cipatat Kolot were not perpetuated. One of the cultural assetsthat should be conserved is the grave of Buyu Cipatat which is well known as an elder. It should be conserved because of his name Kampung Cipatat Kolotis respected by other traditional village and in the line of Banten Kidul customs.

Keywords: Dynamics, Cipatat Kolot, Traditional Village. 


\section{A. PENDAHULUAN}

Masyarakat Indonesia merupakan masyarakat yang bersifat majemuk baik dari segi suku bangsa maupun dari segi budayanya. Kemajemukan ini diterjemahkan dalam falsafah Bhinneka Tunggal Ika yang artinya berbeda-beda (suku bangsa) namun memiliki satu tujuan (Indonesia yang Adil dan Makmur). Apabila dilihat secara mendalam, dari sekian banyak suku bangsa di Indonesia, budaya yang mereka pahami dan laksanakan memiliki kandungan nilai budaya yang sangat luhur. Kearifan lokal dari sebuah suku bangsa menempatkan ranking paling tinggi dalam menjaga keutuhan sebuah suku bangsa karena menjadi pedoman dalam interaksi baik antar-sesama (manusia), maupun dengan alam lingkungannya.

Ciri khas budaya yang selalu bergerak mengikuti alur yang dikehendaki masyarakat $^{1}$ yang disebabkan baik oleh faktor penarik (pull factor) maupun faktor pendorong (push factor) mengakibatkan sebuah suku bangsa bergerak di dua sisi yang berlawanan. Di satu sisi mengembangkan kebudayaannya dengan berpedoman pada nilai luhur budaya tersebut, ataupun justru sebaliknya, suku bangsa tersebut bergerak menjauhi nilainilai luhur dari budaya yang dahulu pernah mereka junjung tinggi.

Globalisasi yang bersifat ekspansif seakan menggerogoti sedikit demi sedikit tatanan budaya sebuah suku bangsa sehingga lama kelamaan nilai luhur mereka mulai digantikan oleh nilai baru yang tidak sama sekali mendukung nilai budaya asli yang mereka anut (dahulunya). Perkembangan teknologi informasi menambah arus persebaran globalisasi

\footnotetext{
${ }^{1}$ Masyarakat sebagai kesatuan hidup manusia yang saling berinteraksi dengan menggunakan sarana dan prasarana yang ada. Sarana yang dimaksud adalah mengarah pada segi kesamaan bahasa sehingga tiap anggota masyarakat dapat berkomunikasi satu sama lain (Koentjaraningrat, 1981: 143-146).
}

semakin tidak terbendung oleh jarak ataupun kondisi geografis. Tayangan televisi dan dunia cyber membawa dan memudahkan pergeseran dan perubahan unsur-unsur budaya tradisional.

Provinsi Jawa Barat sebagai wilayah penyangga ibukota negara RI merupakan provinsi dengan tingkat multikultur yang tergolong cukup tinggi. Pengertian multikultur di sini tidak saja oleh adanya migrasi ulang alik atau permanen dari berbagai suku bangsa di Indonesia. Kultur asing (global) juga menjadi bagian dari keberagaman kultur yang ada di Provinsi Jawa Barat. Secara tidak langsung, efek multikultur ini telah mengakibatkan pergeseran budaya Provinsi Jawa Barat yang identik dengan karakter kesundaannya. Alhasil, struktur bahasa Sunda sedikit demi sedikit mulai dimasuki unsur bahasa lain. Tidak hanya itu, keseganan dan kewibawaan terhadap tokoh masyarakat sudah mulai diisi dengan unsur demokrasi yang "berlebihan".

Dinamika sebuah komunitas adat selalu dilingkupi oleh adanya unsur sosial budaya baru atau asing yang berada di sekitar lingkungan komunitas tersebut. Dengan kata lain, dinamika sebuah sistem sosial akan selalu menghadapi pergeseran atau bahkan perubahan sosial dalam berbagai bentuk. Harwantiyoko, dan Neltje F.Katuuk (tanpa tahun: 82) memperinci beberapa bentuk perubahan sosial di antaranya :

- Perubahan yang terjadi dalam struktur dan fungsi masyarakat (Kingsley Davis),

- Perubahan sosial yang terjadi dalam hubungan sosial (social relationship) ataupun keseimbangan dalam pola hubungan sosial (equilibirium) (Mac Iver),

- Perubahan sosial merupakan suatu variasi atau akibat dari perubahan kondisi geografis, kebudayaan material, komposisi penduduk, ideologi, serta adanya difusi (penemuan baru dalam masyarakat) (Gillin dan Gillin), 
- Perubahan sosial diakibatkan oleh adanya perubahan dalam lembaga kemasyarakatan sehingga berperan dalam memengaruhi nilai-nilai, sikap, dan pola perilaku di antara kelompok masyarakat (Selo Soemardjan).

Pergerakan perubahan memang tidak secara frontal memasuki sistem dan nilai budaya yang ada di Provinsi Jawa Barat. Ada beberapa "kantong-kantong budaya" di Jawa Barat yang hingga saat ini masih memegang teguh prinsip-prinsip budaya luhur mereka. Kasepuhan, komunitas adat, ataupun kampung adat adalah wilayah yang memang diatur sedemikian rupa oleh para tokoh adat dengan berpedoman pada hukum adat dan nilai-nilai budaya dari nenek moyang mereka. Pentingnya hukum (adat) dalam pengaturan sebuah masyarakat umum ataupun masyarakat adat secara garis besar menurut Ihromi (tanpa tahun: 8) bahwa hukum dipandang secara integrasi dalam kebudayaan, hukum tidak terpisah dari kategori pengendalian sosial lainnya dan hukum yang ditekuni adalah hukum dalam aneka jenis masyarakat. Meski ada perbedaan persepsi antara ahli hukum dengan ahli kebudayaan mengenai sah atau tidaknya ranah hukum menjadi bagian dari ilmu kebudayaan namun keperluan atribut hukum dalam sebuah kampung menjadi diperlukan untuk menjaga kelangsungan pranata yang telah dibuat sebelumnya.

Terkait dengan hal tersebut, Koentjaraningrat (tanpa tahun: 29-30), menjelaskan bahwa terdapat 4 atribut hukum yang secara tidak langsung menjadi bagian dalam susunan aturan sebuah kampung adat, yaitu atribut kekuasaan, atribut batas waktu, atribut besaran sanksi, dan atribut jenis sanksi. Di antara 4 buah atribut tersebut, atribut kekuasaan memegang posisi sentral karena sebuah komunitas atau kampung adat harus mempunyai struktur kekuasaan untuk mempermudah pelaksanaan aturan.

Telah banyak studi budaya pada wilayah komunitas adat yang tersebar di Jawa Barat, di antaranya adalah inventarisasi komunitas adat oleh Dinas Kebudayaan dan Pariwisata Provinsi Jawa Barat yang telah mengumpulkan sebanyak 8 komunitas adat, yaitu: Kampung Urug, Kampung Ciptagelar, Kampung Adat Mahmud, Kampung Pulo, Kampung Naga, Kampung Kuta, Kampung Dukuh, dan Kampung Sinarresmi (Bidang Kebudayaan Disbudpar Provinsi Jabar, 2009: 1-26). Hasil inventarisasi dari Dinas Kebudayaan dan Pariwisata Provinsi Jawa Barat dapat dikatakan bersifat sementara karena dimungkinkan masih ada kampung adat yang luput dari inventarisasi tersebut. Salah satu yang telah teridentifikasi adalah Kampung Cipatat Kolot, Desa Kiarapandak, Kecamatan Sukajaya Kabupaten Bogor. Sangat beralasan, pada waktu itu, untuk menyatakan bahwa Cipatat disebut sebagai kampung adat karena telah disahkan melalui surat Depdikbud nomor 440/I-02.5-24/J.1988 yang menyatakan bahwa Kampung Cipatat - beserta dengan Kampung Urug dan Kampung Sihuut sebagai:

a. Kampung adat yang mempunyai nilainilai sejarah dan tradisional serta mempunyai benda-benda peninggalan sejarah/purbakala.

b. Merupakan sumber ilmiah.

c. Peninggalan budaya yang semuanya harus dilestarikan.

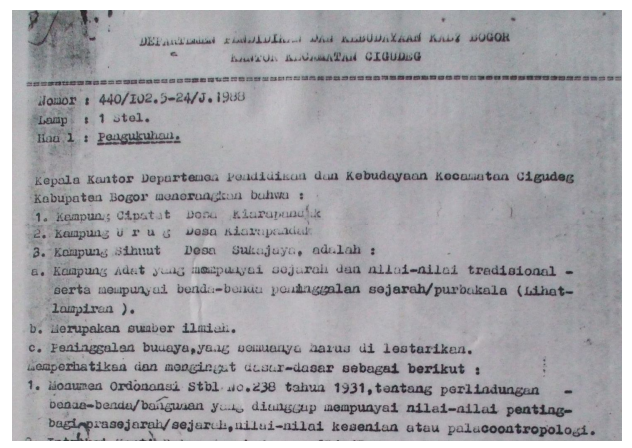

Gambar 1. Cuplikan Surat Depdikbud Nomor 440/I-02.5-24/J.1988.

Sumber. Dokumentasi BPNB Bandung, 2012. 
Referensi mengenai kondisi sosial dan budaya mengenai Kampung Cipatat Kolot saat ini yang sangat minim harus ditanggapi dengan program pelestarian aset sejarah dan budaya yang tentunya dilakukan dalam berbagai bentuk dan salah satu di antaranya adalah mendata dan mengkaji seluruh aset budaya dan sejarah, termasuk di dalamnya adalah aspek-aspek apa saja yang mulai bergeser atau bahkan telah berubah. Beranjak dari kondisi tersebut, dua hal yang menjadi sangat penting artinya dalam penelitian utamanya mengenai dinamika kampung adat Cipatat Kolot mencakup:

- Unsur budaya apa saja yang dapat direkam sehingga membuat Kampung Cipatat Kolot disahkan menjadi sebuah Kampung Adat.

- Dinamika sosial budaya yang mengarah pada keterbukaan terhadap budaya modern.

\section{B. METODE PENELITIAN}

Penelitian mengenai Kampung Cipatat Kolot merupakan sebuah penelitian yang bersifat eksplorasi karena hasil yang dicapai dalam pencarian referensi sekunder mengenai deskripsi lokasi penelitian adalah sangat minim atau bahkan dapat dikatakan tidak ada sama sekali. Metode yang digunakan bersifat deskriptif kualitatif sementara mengenai analisa data dilakukan dengan memanfaatkan data-data primer dan sekunder yang telah terkumpul.

Teknik pengumpulan data menjadi bagian yang sangat penting dan harus diupayakan seakurat mungkin. Oleh karena itu, diperlukan beberapa teknik pengumpulan data yang diupayakan dapat menyisir seluruh data ragam budaya yang ada di Kampung Cipatat Kolot. Adapun data yang akan digali merupakan data kualitatif dengan menggunakan teknik purposive sampling

Data yang diperlukan mencakup dua jenis, yaitu data primer dan data sekunder. Data sekunder dapat ditelusuri melalui studi pustaka ke perpustakaan, baik pusat maupun daerah. Dapat pula ditelusuri melalui pencarian naskah-naskah kuno di lokasi penelitian. Sebagaimana telah dikemukakan bahwa data sekunder dalam penelitian ini adalah sangat minim sehingga kekuatan dari penelitian ini dicapai melalui pencarian data primer. Dengan demikian data sekunder yang dicari adalah sebagai bahan perbandingan antara Kampung Cipatat Kolot dengan kampung adat lainnya dalam lingkup Provinsi Jawa Barat.

Data primer merupakan primadona dari seluruh data mengenai keragaman budaya di kasepuhan Cipatat. Data ini merupakan sumber langsung yang diperoleh dari informan, informan kunci, ataupun responden yang mendukung penguatan data dari informan/informan kunci. Khusus mengenai pencarian data primer, diperlukan rambu-rambu atau kerangka pertanyaan dalam bentuk pedoman wawancara yang berfungsi untuk mengarahkan pertanyaan pada tujuan pokok penelitian ini. Peralatan lainnya yang diperlukan kaitannya dengan pendokumentasian data adalah dengan menggunakan tape recorder, kamera, dan handycam.

\section{HASIL DAN BAHASAN}

\section{Gambaran Umum Lokasi Penelitian}

Kampung Cipatat Kolot berada sekitar $3 \mathrm{~km}$ dari Kampung Urug Desa Kiarapandak, Kecamatan Sukajaya, Kabupaten Bogor. Adapun Desa Kiarapandak berbatasan dengan:

- Sebelah utara berbatasan Desa Harkatjaya.

- Sebelah selatan berbatasan dengan Desa Kiarasari dan Desa Cisarua.

- Sebelah timur berbatasan dengan Kecamatan Nanggung.

- Sebelah barat berbatasan dengan Desa Pasir Madang.

Desa Kiarapandak, Kecamatan Sukajaya, berada dekat perbatasan dengan Provinsi Banten, atau tepatnya bersebelahan pada bagian timur dengan Kabupaten Lebak. Kedekatan dengan 
Provinsi Banten menimbulkan adanya asumsi bahwa ada keterkaitan antara Kampung Cipatat Kolot dengan Kasepuhan Adat Banten Kidul. Hal ini terkuak melalui paparan Nugraheni (2002: 11) yang mengatakan bahwa Kasepuhan Adat Banten Kidul mendiami tiga kabupaten dalam dua provinsi, yaitu Provinsi Jawa Barat (Kabupaten Bogor dan Kabupaten Sukabumi), dan Provinsi Banten (Kabupaten Lebak). Lebih lanjut lagi, Nugraheni mendeskripsikan kasepuhan-kasepuhan yang mendiami tiga kabupaten tersebut, yaitu:

- Di Kecamatan Jasinga (Kab. Bogor) meliputi Kasepuhan Gajrug, Sajira, dan Guradog;

- Kecamatan Bayah (Kab. Lebak) meliputi Kasepuhan Tegal Lumbu, Cicarucub, Cisungsang, Cicemet, Sirnagalih, Cikadu, dan Citorek;

- Kecamatan Cigudeg ${ }^{2}$ dan Sukajaya (Kab. Bogor) meliputi Kasepuhan Urug, Pabuaran, dan Cipatat Kolot;

- Kecamatan Cisolok (Kab. Sukabumi) meliputi beberapa kasepuhan yang berada di sepanjang Sungai Cibareno Girang, yaitu Kasepuhan Ciptarasa dan Ciptagelar.

Berlanjut ke kondisi iklim di lokasi penelitian yang kurang lebih adalah sama dengan kondisi iklim di Kecamatan Sukajaya khususnya dan wilayah Kabupaten Bogor pada umumnya, yaitu iklim tropis tipe A (sangat basah) di bagian selatan dan tipe B (basah) di bagian utara. Suhu berkisar rata-rata antara 20 derajat sampai dengan 30 derajat celcius. Curah hujan tahunan antara $2.500 \mathrm{~mm}$ sampai lebih dari $5.000 \mathrm{~mm} /$ tahun. Begitu juga halnya dengan ketinggian rata-rata berkisar antara $15-2.500$ M Dpl, dengan penyebaran sebagai berikut: berkisar antara 15 - $2.500 \mathrm{M} \mathrm{Dpl,} \mathrm{daratan} \mathrm{bergelombang}$ (100-500M) di bagian tengah, pegunungan

2 Kecamatan Cigudeg dimekarkan dan membentuk Kecamatan baru yaitu Kecamatan Sukajaya.
(500-1000 M), pegunungan tinggi dan daerah puncak (2000-2.500 M).

Dari segi pekerjaan, sebagian besar masyarakat Desa Kiarapandak bermata pencaharian sebagai petani, hal ini sesuai dengan luas wilayah. Penggunaan tanah sebagian besar digunakan untuk sawah yaitu sebanyak 259.570 ha. Secara umum keadaan topografi Desa Kiarapandak merupakan daerah dataran dan perbukitan dengan iklim kemarau dan penghujan. Hal ini berpengaruh terhadap pola tanam yang ada di Desa Kiarapandak seperti yang tampak pada tabel di bawah ini.

\section{Tabel 1: Sebaran Luas Wilayah Penggunaan Tanah No Penggunaan Tanah Luas (Ha) \\ 1 Sawah 259.570 \\ 2 Kebun 235 \\ 3 Pekarangan $\quad 15.130$ \\ 4 Tegal 253.474 \\ 5 Hutan 2,0 \\ 6 Lainnya 3,5 \\ Total \\ $528.414,5$}

Sumber: BPS Kab. Bogor, 2012

Jumlah penduduk Desa Kiarapandak berdasarkan data statistik Kabupaten Bogor tahun 2012 yaitu sebanyak 10.307 jiwa, yang terdiri atas 5.419 jiwa laki-laki dan 4.888 jiwa perempuan dengan jumlah kepala keluarga 2.321 jiwa. Desa Kiarapandak terdiri atas lima dusun, 14 RW, dan 50 RT dengan jumlah keluarga miskin sebanyak 558 jiwa. Ditinjau dari segi agama, mayoritas penduduk Desa Kiarapandak beragama Islam dan sisanya beragama Katolik dengan jumlah masjid dan mushola masing-masing 15 dan 14 buah.

\section{Ragam Budaya Kasepuhan Cipatat Kolot}

a. Religi

Berdasarkan pengamatan di lokasi penelitian, tampak bahwa sebagian besar atau dapat dikatakan seluruhnya masyarakat Kampung Cipatat Kolot saat 
ini menganut agama Islam. Hal ini terlihat dari beberapa surau dan masjid yang tegak berdiri pada beberapa lokasi seputar Kampung Cipatat Kolot. Saat menjelang magrib, tampak kaum lelaki dewasa bersarung berada di sekitar surau sambil menunggu azan magrib.
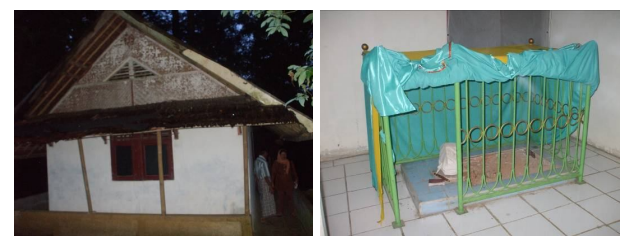

Gambar 2. Bangunan dan Bentuk Makam Sesepuh Kampung Cipatat Kolot.

Sumber Dokumentasi BPNB Bandung, 2012.

Pengaruh ajaran agama Islam memang terasa di Kampung Cipatat Kolot setelah sebelumnya - pada zaman dahulu sempat didominasi ajaran agama Sunda Wiwitan. Walaupun Islam telah masuk dan diterapkan oleh masyarakat Kampung Cipatat Kolot, namun ajaran agama sebelumnya dapat dikatakan telah melebur hingga menciptakan keseimbangan serasi antara Islam dan Sunda Wiwitan. Keserasian ini memang diperlukan mengingat konsep pelestarian alam, kesederhanaan, dan saling menghormati kepada sesama telah terinci dalam konsep ajaran Sunda Wiwitan. Dengan adanya keterpaduan tersebut, konsep tabu, ritual, dan upacara tradisional pada masyarakat Cipatat Kolot masih berlaku sampai dengan masuknya modernisasi terutama sektor transportasi dan komunikasi yang mempermudah proses ulang alik baik dari segi kebendaan ataupun trend yang ada di "dunia luar". Kemudahan ini membuat masyarakat menjadi gamang dengan keteguhan mereka terhadap prinsip budaya mereka sendiri. Apakah mereka tetap berperilaku seperti sediakala ataukah melangkah keluar dan mengikuti trend yang ada di kota besar. Apalagi dengan adanya sifat yang bertolak belakang antara prinsip budaya setempat dengan trend perkotaan yang sangat mentabukan sifat yang dianggap berbau "klenik" seperti halnya dengan konsep tabu dan berbagai jenis upacara tradisional yang sangatsangat dihindari pada masyarakat perkotaan.

Tabu merupakan produk budaya tradisional yang berfungsi untuk menjaga masyarakat agar selalu berpijak pada aturan nilai dan norma yang berlaku pada produk budaya yang telah dibuat sebelumnya. Pelaksanaan konsep tabu diungkapkan dalam berbagai bentuk pantangan-pantangan yang sebenarnya memiliki arti positif yang mendalam. Contoh sederhana dari pantangan yang masih berlaku di Kampung Cipatat Kolot adalah dilarang duduk di muka pintu agar tidak jauh jodoh. Salah seorang informan menyatakan bahwa memang pantangan tersebut masih berlaku namun dengan alasan yang lebih "masuk akal", yaitu apabila seseorang gadis duduk di muka pintu tentunya akan tidak sedap dipandang mata. Selain itu, ia tentunya akan menghalangi orang lain yang lalu lalang.
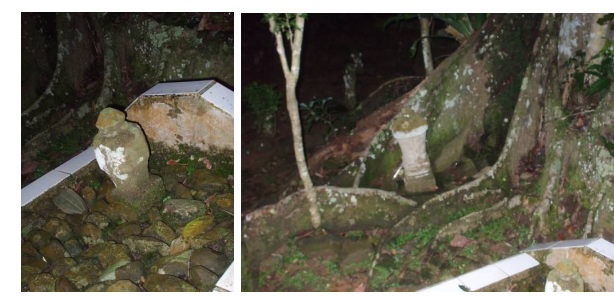

Gambar 3. Salah Satu Bentuk Makam di Sekitar Bangunan Makam Sesepuh Kampung Cipatat Kolot.

Sumber

Dokumentasi BPNB

Bandung, 2012.

Logika-logika umum tersebut di Kampung Cipatat Kolot untuk menjawab tradisi berpantang memang sudah tampak dan mulai menggeser alasan-alasan yang disisipi unsur ramalan serta ketakutan akan makhluk gaib. Walaupun demikian, hal ihwal makhluk gaib untuk lingkup pedesaan memang selalu ada dan hal itu pun masih dipercaya oleh masyarakat Kampung Cipatat Kolot. Kepercayaan ini 
setidaknya secara tidak langsung turut menjaga peninggalan benda-benda budaya seperti yang ada di situs makam keramat yang tidak jauh dari pemukiman penduduk.

Kondisi lingkungan di sekitar makam terlihat masih asri dan ditumbuhi rerimbunan pohon tua berusia ratusan tahun. Nisan-nisan "tua" (gambar 3) yang bernilai sejarah dan ekonomis tinggi masih terlihat utuh dan tidak - atau belum tersentuh tangan-tangan jahil untuk diperdagangkan.

Kondisi makam sesepuh Kampung Cipatat Kolot (gambar 2) terlihat terpelihara yang menandakan bahwa masih ada rasa hormat dan kerelaan dari pengurus makam (terutama) untuk merawat dan menjaga makam tersebut. Konsep tabu dalam bentuk ritual saat memasuki makam juga masih ditaati. Mulai dari saat membuka pintu, memasuki ruang makam, membuka dan menutup kembali tirai makam, serta menutup pintu makam (saat hendak keluar) terlihat pengurus makam membaca doa-doa tertentu (dalam hati). Hening dan perilaku pengurus makam amat memperhatikan tatakrama kesopanan di dalam areal makam.

Di dalam bangunan makam juga terlihat ada tempat khusus untuk sesaji yang pada waktu-waktu tertentu akan diganti dengan yang baru. Ataupun apabila ada tamu khusus - biasanya tamu adat yang datang akan membawa sesaji dan diletakan pada tempat yang disediakan seperti terlihat pada gambar 4 di bawah ini.

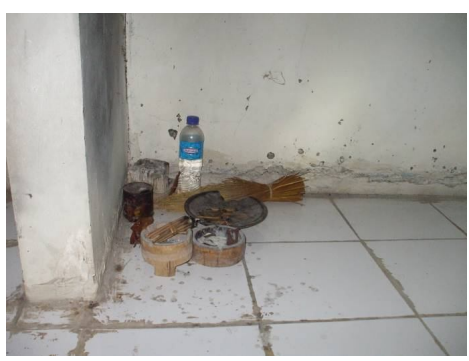

Gambar 4 Tempat Sesaji dalam Bangunan Makam Keramat.

Sumber Dokumentasi BPNB Bandung, 2012.
Tamu yang datang baik perorangan ataupun rombongan tidak begitu saja datang sebentar lalu pergi. Mereka biasanya akan menunjukkan rasa hormat dalam bentuk pembacaan doa-doa tertentu. Untuk hal tersebut, di dalam bangunan makam telah disediakan alas berupa tikar dan bantal (gambar 5) untuk digunakan para tamu yang hendak berdoa di dalam makam keramat tersebut.

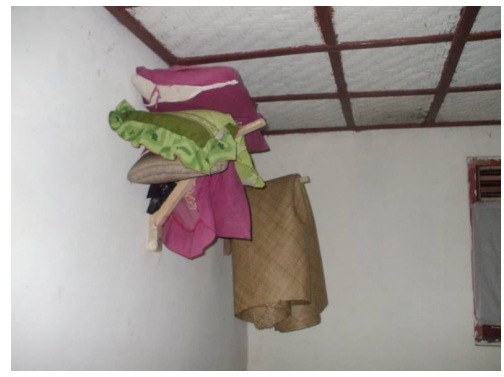

Gambar 5. Tempat alas (tikar) yang diletakkan di atas sudut bagian dalam bangunan makam.

Sumber Dokumentasi BPNB Bandung, 2012.

\section{b. U pacara Tradisional}

Pemenuhan unsur religi akan tidak lengkap apabila tidak diikuti dengan adanya upacara atau ritual tradisional. Di antara ritual tersebut adalah mengenai proses peminangan. Salah satu syarat seorang pemuda yang hendak meminang gadis di Kampung Cipatat adalah bahwa sang pemuda harus bisa menganyam atap rumah yang terbuat dari daun aren. Sementara sang gadis harus bisa nutu pare 'menumbuk padi'.

Setiap warga masyarakat Cipatat Kolot akan melakukan sebuah pekerjaan atau maksud tertentu, seperti hajatan, baik perkawinan maupun khitanan atau hajatan lainnya; selalu didahului dengan upacara ngangkat. Pengertian ngangkat ini sama dengan upacara ngadiukkeun, yakni upacara memasukkan padi ke dalam leuit, lumbung. Tujuannya adalah agar rezeki 
berupa apa pun cukup memenuhi kebutuhan, bahkan berlebih. Hal ini sesuai dengan pedomannya berupa ungkapan saeutik mahi loba nyesa.

Upacara ngangkat pada dasarnya adalah upacara memohon doa restu kepada abah atau kokolot (sesepuh kampung adat). Tujuannya tidak lain agar segala maksud dapat berjalan dengan selamat, tertib dan lancar. Prosesnya pun sederhana, seorang pemangku hajat, biasanya orang tua, datang kepada Abah. Ia mengemukakan maksud tujuannya. Misalnya akan melaksanakan khitanan atau sunatan. Selanjutnya, Abah pun mendoakan dan memberi nasihat. Hal itu berlangsung sesuai kebutuhan dalam waktu yang tidak lama dengan hari pelaksanaannya. Biasanya sehari atau menjelang pelaksanaan hajatan. Demikian pula dalam proses sunatan pada tradisi turun ronda, yakni sebelum dilaksanakan tradisi tersebut, pemangku hajat melakukan dahulu upacara ngangkat di Bumi Ageung tempat Abah tinggal.

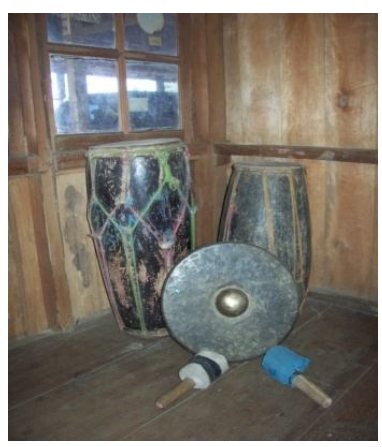

Gambar 6 Dua alat kesenian (kempul dan kendang) yang masih tersisa dan diletakkan di Bumi Ageung.

Sumber

Dokumentasi BPNB

Bandung, 2012.

Upacara ngangkat bisa saja berlangsung beberapa saat sebelum anak disunat atau bisa jadi menjadi titik awal dimulainya turun ronda. Beberapa saat menjelang disunat, sang anak "direndam" di sebuah kolam atau bak air. Waktu perendaman biasanya setelah azan subuh. Maksud perendaman ini tidak lain untuk membuat baal alat vitalnya. Setelah dirasa cukup baal, sang anak dimandikan dan diberikan baju sunat berupa sarung dan baju tikim (zaman dulu) sejenis piama atau baju kampret (sejenis baju koko). Selanjutnya, pengantin sunat disertai keluarganya berangkat menuju balai desa untuk disunat. Selama perjalanan mengarak pengantin sunat, selama itu pula kesenian turun ronda terus ditabuh. Kesenian turun ronda terdiri atas 2 (dua) buah kendang pangarakan dan 2 (dua) buah gong yang disebut kempul dan bende.

Pengarakan pengantin sunat harus memperhitungkan "kebaalan" alat vitalnya. Prinsipnya saat disunat oleh bengkong 'dukun sunat' pengantin sunat tidak kesakitan yang amat sangat. Jika hal itu terjadi, bisa disebabkan kebaalannya sudah banyak berkurang. Oleh karena itulah, waktu penyunatannya diupayakan pagi hari antara pukul $05.00-07.00$.

Selanjutnya, untuk menghibur pengantin sunat diadakan hiburan berupa tontonan dalam bentuk seni kendang penca dan atau upacara baksa. Upacara baksa di sini dalam pengertian melakukan engkle 'lomba berjingkit' pada jarak tertentu antara pengantin sunat dengan anak lain yang seumur. Caranya adalah baik pengantin sunat maupun anak orang lain diais 'digendong' oleh dua orang remaja atau dewasa atau orang tua. Pada titik tertentu mereka memulai start dan berakhir pada titik yang lain yang tidak terlalu jauh jaraknya. Berjalan atau berlari adu cepat dengan mengangkat salah satu kaki merupakan hiburan tersendiri bagi sang pengantin sunat.

Kedua orang tua sangat mengharapkan anaknya menjadi orang yang berguna dunia akhirat. Doa dan nasihat kepada pengantin sunat senantiasa diucapkan oleh para handai taulan atau para undangan sambil memberikan uang panyecep. Namun sebelum itu terlebih dahulu dilakukan upacara sawer pengantin sunat. Sawer adalah kiat orang tua dalam 
memberi nasihat kepada putra-putrinya dalam bentuk lagu atau nyanyian. Pada waktu saweran terdapat pula alat-alat sawer-nya berupa: uang, baik logam maupun kertas; beras, koneng (temulawak); gula-gula (permen); dan benda lain yang dapat meramaikan suasana. Peralatan ini disela-sela lagu sawer dilemparkan ke para undangan atau penonton yang sudah bersiap untuk moro (mengejar dan mengambil benda yang disawer).

Adapun makanan yang harus ada pada setiap sunatan adalah ayam panggang dalam bentuk yang disebut ayam bakakak. Dalam bahasa mereka, warga Cipatat Kolot, adanya ayam bakakak adalah panutas panyecep getih panyombo budak, penutup penyumbat darah penggembira anak. Di samping terdapat pula sangu congcot (nasi congcot); nasi putih yang dibentuk seperti kerucut.

Proses sunatan anak di atas, merupakan "nostalgia" masa lalu yang saat ini sudah tidak dilakukan lagi, terutama acara mengaraknya. Tak ada lagi arakarakan (turun ronda) atau upacara baksa. Pada saat sekarang, cukup sekeluarga pagi hari pergi ke dokter dan memakaikan baju koko kepada anak yang akan disunat, maka acara sunatan pun selesai. Namun demikian, ada beberapa rangkaian sunatan yang tidak berubah atau masih dilaksanakan hingga kini, yaitu: ngangkat (meminta doa restu kepada kokolot di imah gede), makanan tradisional, seperti: ayam bakakak dan sangu congcot; sawer sunat (bagi yang mampu); dan panyecep (memberikan uang kepada anak sunat). Sementara hiburan tidak menjadi pilihan utama, bahkan tidak terencanakan, kecuali untuk orang kaya.

Masyarakat kasepuhan Cipatat Kolot yang memiliki mata pencaharian sebagai petani kerap melakukan upacara adat seren taun merupakan satu acara penting yang diselenggarakan setiap tahun. Ada satu kekhasan dalam acara ini, yaitu bahwa Kampung Cipatat menjadi lokasi sentral untuk membicarakan upacara yang diselenggarakan oleh beberapa kampung adat, khususnya di Kiarapandak, yaitu Kampung Cipatat Kolot, Kampung Urug, dan Kampung Cihuut. Sekadar pembicaraan yang merupakan satu syarat biasa namun harus dipenuhi oleh kedua kampung tersebut sebelum mengadakan upacara seren taun. Sementara upacara tersebut dilakukan oleh masing-masing kampung adat.

Menurut informan bahwa dalam perayaan upacara seren taun yang dilakukan oleh masyarakat kasepuhan Banten Kidul tidak jarang para petinggi kasepuhan melakukan ngembang (berziarah) ke makam tersebut. Tahapan ngembang merupakan awal dari rangkaian upacara seren taun sebelum melakukan tahapan selanjutnya. Petinggi kasepuhan biasanya terdiri atas sesepuh girang beserta baris kolot.

Selain dalam rangkaian pra perayaan upacara seren taun, tradisi ngembang atau biasa juga disebut dengan ziarah lembur juga dilakukan setiap tahun setelah hari raya idul fitri. Ziarah yang ditujukan untuk melakukan penghormatan kepada makam buyut Cipatat atau Eyang Pandita (gambar 2) dilaksanakan oleh seluruh warga Cipatat Kolot yang dipimpin oleh Abah Acim selaku sesepuh Cipatat Kolot.

Ritual ini dimulai dari Bumi Ageung yang sudah dipenuhi oleh berbagai macam makanan dan penganan yang dibawa oleh warga dan dikumpulkan di Bumi Ageung. Di antara menu makanan tersebut terdapat bakakak hayam, ati ampela, nasi kuning, sate kambing, nasi uduk, dan berbagai macam buah. Sebagian di antara warga ada juga yang menyerahkan uang dan beberapa bungkus rokok dari berbagai merek namun sebagian besar dari jenis rokok kretek.

Menurut informan, di lokasi makam Buyut Cipatat, Olot Cipatat Kolot membacakan doa-doa berbahasa Arab dan Sunda disertai dengan kepulan kemenyan. Selain doa yang dipimpin Olot, doa juga dibawakan oleh ustadz yang membacakan tawasul. Setelah rangkaian doa selesai, warga dipersilahkan ke Bumi Ageung 
untuk bersantap. Sambil bersantap, perwakilan masyarakat Cipatat Kolot mengikuti acara pembagian kemenyan dan panglay untuk dibagikan kembali kepada warga. Dua jenis barang tersebut diharapkan dapat membawa keselamatan dan keberkahan dari Yang Maha Kuasa. ${ }^{3}$

\section{c. Kesenian}

Perubahan kondisi masyarakat yang demikian besar itu dapat dilihat pula dalam kesenian tradisionalnya. Kebanyakan masyarakat sudah meninggalkan atau tidak melakukan lagi tradisi yang berkaitan dengan keseniannya. Misalnya, kesenian turun ronda pada adat sunatan atau khitanan. Namun demikian, informan menerangkan bahwa pada dasarnya mereka masih mengenal dan bisa memainkan alat kesenian tradisional, terutama gamelan. Hanya masalahnya adalah ketidaktersediaan fasilitas. Dahulu pernah salah seorang warga yang memiliki seperangkat gamelan, sehingga mereka dapat berlatih atau bermain pada waktu senggang. Tetapi setelah gamelan itu dijual pemiliknya, maka mereka pun tidak dapat berbuat apa-apa. Oleh karena itu, sebagian warga masih mengenal betul mengenai kesenian, turun ronda, topeng, jipeng, jaipongan, dan wayang golek. Sementara itu kesenian tradisional yang menjadi ciri khas kampung adat, yaitu angklung atau dogdog lojor tidak mereka miliki. Apabila mereka memerlukan kesenian tersebut, mereka meminta bantuan kepada kampung lain yang masih ada keterkaitan dengan kampungnya.

Di lain pihak, kaum muda lebih menyenangi kesenian "modern" yaitu lagulagu pop, dan lagu-lagu dangdut. Sementara itu, hiburan yang pada pesta perkawinan atau khitanan atau pun pesta

3 Ritual ini sebelumnya juga telah dipublikasikan dalam "Ziarah Salembur Kasepuhan Adat Cipatat Kolot Sukajaya Bogor", http://kalakayjasinga.blogspot.com/ 2009/11/ziarah-salembur-kasepuhan-adatcipatat.html tanggal 16 Nopember 2009. pada acara lainnya kesenian yang disenangi adalah organ tunggal.

\section{1) Turun Ronda}

Seni turun ronda pada dasarnya sama dengan jenis kesenian helaran di wilayah Priangan, yaitu arak-arakan. Pada seni helaran beberapa kesenian beriringan para pelakunya melakukan pertunjukan sambil berjalan dari satu tempat ke tempat lain. Sifatnya meriah, ramai dan memerlukan jumlah pemain yang banyak. Biasanya dilakukan dalam kerangka memamerkan hasil karya pembangunan di pedesaan. Oleh karena itu, helaran tidak berdiri sendiri hanya melulu jenis kesenian saja, melainkan disertai dengan memamerkan hasil-hasil pertanian dengan cara mengarak menggunakan jampana atau dongdang. Berbeda dengan helaran, seni turun ronda adalah mengarak pengantin sunat dari rumahnya menuju balai desa.

\section{2) Topeng}

Masyarakat Cipatat Kolot menyebut topeng untuk kesenian yang memadukan unsur teater rakyat dengan iringan gamelan tradisional. Sebutan topeng merupakan sebutan awam untuk menyebutkan kesenian jipeng yang juga akronim dari tanji dan topeng. Tanji dalam kesenian Betawi adalah jenis kesenian teater dengan iringan musik tanjidor yang mulai berkembang sekitar tahun 1940 dan tidak jauh berbeda dengan kesenian topeng Betawi (Setyaningrum, 2011: 23) Tanji adalah musik tradisional Sunda dengan instrumen-instrumen Barat, seperti : bedug, tambur, tuba, bangsing, tarompet, horent, trombol, kecrek. Di dalam perkembangannya, tanji berwaditra Sunda, instrumen-instrumen Barat menghilang diganti dengan kendang, saron I, saron II, gendang, kecrek, goong, kromong tiga, dan rebab atau biola. Salah seorang penari tanji yang dipandang sebagai primadona masih mempunyai fungsi lain yakni sebagai pasangan bodor dalam acara lawak sebelum lakon dimulai. 
Fungsi lain seni tanji adalah digunakan dalam mengarak pengantin, upacara mapag panen (menyambut panen), upacara sedekah bumi, ngaruat jagat, mengarak anak khitanan. Susunan lagu yang dimainkan ialah : Kembang Gadung, Kidung Rahayu, Buah Kawung, serta Geboy; ditambah dengan lagu-lagu yang digemari penonton.

Topeng dalam bahasa Sunda berarti kedok, teregos. Fungsinya adalah menutupi wajah dengan bentuk lain. Namun demikian arti dan fungsi ini dalam seni topeng tidak tergambarkan. Artinya, pada topeng tak pernah mengenal tarian yang para pemainnya mempergunakan kedok. Kostum para penarinya hanya seadanya saja, yang berarti tak pernah menggunakan kostum khusus seperti penari.

Sebenarnya sebutan topeng tidak tepat atau kurang lengkap apabila merujuk pada pengertian seperti yang kita kenal sebagai kedok. Dalam bahasa Betawi istilah topeng berarti tontonan, sandiwara, penari atau primadona. Dalam kata topeng monyet pengertiannya adalah tontonan, sedangkan dalam topeng tanji dapat berarti tarian atau penarinya dan dalam menyebutkan nama penari wanita terbaik dalam sebuah grup sebagai “topeng'nya berarti primadona.

\section{3) Jipeng}

Entah kenapa masyarakat Cipatat Kolot menyenangi seni jipeng yang merupakan kesenian teater yang kini khas menjadi salah satu aset budaya Betawi. Kejelasan yang dapat dilihat bahwa faktor kelucuan dalam pertunjukan jipeng ini memicu masyarakat Cipatat Kolot untuk menyenangi seni jipeng.

Kesenian jipeng sebenarnya bukanlah mutlak kesenian yang lahir di tanah Betawi melainkan kesenian yang tumbuh di daerah Jawa Barat namun tenar di kalangan masyarakat Betawi.

Perkataan "Jipeng" yang merupakan singkatan tanji dan topeng berarti sandiwara yang diiringi dengan musik tanjidor. Pada masa lalu pertunjukan
Jipeng umumnya berlangsung hampir sehari-semalam dan satu-satunya pemain yang mengenakan topeng atau kedok hanya pemain "Bapa Jantuk" yang muncul hanya pada dua jam terakhir. Dewasa ini pertunjukan jipeng (topeng) tidak seketat masa lalu, melainkan disesuaikan dengan permintaan. Biasanya berlangsung malam hari hingga menjelang pagi. Adapun cerita yang ada di antaranya Babad Banten, Babad Bogor, Ciung Wanara, dan Regen Bandung. Adapula yang membawakan cerita-cerita seperti "Sultan Majapahit, "Perabu Siliwangi", "Babat Bogor", "Sinden Siluman", "Rindon Jago Kerawang" dan lain-lain.

Hal yang disenangi penonton pada seni jipeng adalah saat kemunculan pemain yang berperan sebagai bodoran, pelawak. Kelucuan yang dibalut dalam cerita rakyat menjadikan topeng ini disenangi penonton. Di samping itu, para penari dan pesinden (biasanya merangkap) turut pula menyemarakkan suasana. Di sela-sela cerita -sebagai selingan- hentakan gendang yang dinamis dan "rayuan" pesinden dengan suaranya yang merdu mengajak penonton untuk turun menari.

Dalam pertunjukannya, jipeng menampilkan permainan masik, tari-tarian dan aksi teater treatrikal atau perpaduan gerak dan teater. Kesenian jipeng ini, mirip dengan seni drama yang memiliki alur cerita lakon dan babak. Pada umumnya mengambil tema cerita tentang keagamaan atau petuah.

Jipeng membawakan lagu-Iagu yang menurut istilah setempat disebut lagu-Iagu mars dan was (mungkin berasal dari kata Wals) seperti lagu-Iagu "Kramton, Bataliyon, Was Taktak" dan lain sebagainya, diiringi oleh orkes tanjidor.

Untuk mengiringi tarian yang bentuknya tidak begitu berbeda dari tarian pada pertunjukan topeng kadang-kadang orkes tanjidor diganti dengan kromong tiga pencon, gendang, kecrek, kempul, suling, kempul dan gong buyung. Sering pula terjadi digunakannya orkes tanjidor 
sebagai pengiring tari dalam pertunjukan jipeng.

\section{4) Jaipongan}

Masyarakat Cipatat Kolot dalam mengikuti kesukaan pada kesenian tradisional juga tertarik dengan kesenian jaipong. Keceriaan dalam tari yang biasanya dimainkan pada malam hari ini menjadi nilai tambah sehingga kerap dijadikan sebagai salah satu sarana hiburan dalam acara khitanan, perkawinan, ataupun dalam sebuah perhelatan.

Tari pergaulan yang berdasarkan pada tarian rakyat ketuk tilu yang memasukkan unsur-unsur penca dengan mengurangi unsur-unsur erotiknya yang dipolulerkan oleh Gugum Gumbira, Tati Saleh dan Euis Komariah menjelang akhir tahun 1970-an. Kesenian yang sejenis doger (Karawang), banjet (Subang), longser (Bandung). Alatnya terdiri atas kendang, goong, saron I, saron II, kecrek, rebab, bonang (kromong), demung, dan pesinden ditambah juru alok.

\section{5) Wayang Golek}

Seorang informan mengatakan bahwa dirinya bisa memainkan alat-alat gamelan wayang golek. Dulu, salah seorang warga pernah memiliki seperangkat gamelan. Karena itu atas kebaikannya mereka sering menabuhnya . Namun setelah gamelan itu dijual, kini mereka tidak lagi bisa mewariskan kemampuannya kepada orang lain. Hal yang sering dilakukannya sekarang adalah menjadi penonton atau penikmat saja.

Wayang golek adalah sebuah teater tradisional dalam bentuk boneka. Setiap langkah cerita, baik gerak maupun ucapannya selalu disertai iringan gamelan. Boneka itu digerakkan oleh penggerak yang disebut dalang. Dalang inilah yang menentukan segala sesuatunya dalam kerangka menyampaikan sebuah lakon. Lakon wayang golek bersumber pada cerita Mahabrata dan Ramayana, tetapi dalam praktiknya sering dibawakan lakonlakon sempalan. Informan pun menyatakan cerita wayang golek pun bisa diambil dari cerita babad, seperti Babad Banten. Hal itu semua bergantung pada permintaan pemangku hajat.

Waktu pertunjukan bisa berlangsung sehari semalam atau semalam suntuk. Adapun peralatan wayang golek adalah (1) seperangkat gamelan, baik laras Salendro maupun Pelog, yang terdiri atas kendang, goong, saron I, saron II, kecrek, rebab, bonang (kromong), demung, bedug, (2) Juru kawih 2 (dua orang) atau lebih pesinden ditambah juru alok; (3) seorang atau lebih yang menjadi dalang; (4) aneka wayang, gedebog cau; (5) sesajian.

\section{6) O rgan Tunggal}

Selain menyukai kesenian tradisional, masyarakat Cipatat Kolot juga sudah mulai tertarik dengan seni modern yang salah satunya adalah organ tunggal. Organ tunggal merupakan kesenian yang mencampurkan antara alat musik Barat yaitu organ dengan alat musik tradisional berupa gendang dan goong. Fungsinya adalah untuk mengiringi nyanyian yang dilantunkan penyanyi. Aneka ragam jenis musik yang bisa dibawakan oleh organ memungkinkan setiap orang dapat berinteraksi semaksimal mungkin. Lagulagu baik pop, melayu, regae, maupun dangdut dapat dimainkan hanya dengan sebuah alat musik, yaitu organ. Oleh karena itu, seni organ tunggal sangat digemari, terutama di kalangan orang muda. Di samping itu, personal atau pemain yang sedikit dan cenderung praktis serta murah menjadi daya tarik sendiri dalam hiburan hajatan.

\section{7) Dangdut}

Hampir sama dengan organ tunggal, masyarakat Cipatat Kolot juga menyenangi musik dangdut. Meski sudah ada kesenian organ tunggal namun ada beberapa warga yang mengadakan pergelaran dangdut saat memeriahkan acara khitanan, perkawinan, ataupun perhelatan. Tidak banyak memang yang menyewa kesenian dangdut tersebut karena biaya yang dikeluarkan untuk 
mengundang grup dangdut ke pesta perkawinan atau khitanan cukup besar. Walaupun demikian, ada sebuah kepuasan tersendiri saat mengundang grup dangdut tersebut sehingga mereka (warga) rela mengeluarkan sejumlah uang demi terlaksananya kemeriahan pesta perkawinan atau khitanan anggota keluarganya.

\section{d. B ahasa}

Memasuki rumah Abah Acim yang menyambut dengan ramah, sangat terasa perbedaan dialek ala Cipatat dengan dialek Sunda wilayah Bandung. Kedekatan dengan wilayah Provinsi Banten membuat struktur tata bahasa, logat, dan kata-kata yang diucapkan mengarah pada dialek ala Banten. Pengaruh Banten dalam dialek warga Kampung Cipatat dibenarkan oleh Suriamiharja dalam Kartika (2010: 10), yang menyatakan bahwa terdapat variasi bahasa yang khas di Kabupaten Bogor. Bagian utara sangat dipengaruhi oleh bahasa Betawi, sehingga muncul istilah Betawi Ora (Betawi Sunda). Pada bagian selatan, bahasa Sunda Bogor sangat dipengaruhi oleh gaya bahasa Cianjur dan Sukabumi. Pada bagian barat, bahasa Sunda Bogor sangat dipengaruhi oleh bahasa Sunda Banten. Dan, pada bagian timur, bahasa Sunda Bogor sangat dipengaruhi oleh dialek bahasa Karawang, Cianjur, dan Bekasi.

Tuturan bahasa yang dipergunakan warga Cipatat Kolot yang banyak menggunakan dialek Banten memang sangat kentara. Walaupun demikian, di sela-sela pembicaraan kerap terdengar kata-kata yang menggunakan bahasa Indonesia. Hal ini menjelaskan bahwa terjadi pula dinamika dalam penggunaan bahasa yang mengarah pada akulturasi bahasa atau bahkan menghilangkan "bahasa ibu" itu sendiri.

\section{e. Tata Ruang}

Modernisasi telah mengubah segalanya. Keramaian kini tak hanya ditemukan di perkotaan, melainkan banyak bergeser ke perkampungan. Kampung semakin maju dan berkembang seiring dengan kemajuan warganya. Pertumbuhan jumlah penduduk di kampung pun menjadi semakin tinggi, karena kampung menjanjikan kehidupan yang lebih baik.

Pemandangan itu bisa ditemui di Kampung Cipatat Kolot yang secara administrarif berada di Desa Kiarapandak, Kecamatan Sukajaya, Kabupaten Bogor. Kampung ini berada di tengah persawahan, perladangan, dan perkebunan sawit yang asri. Sebuah leuweung tutupan di sebelah utara terpelihara dengan baik dan menghindarkan seluruh warga dari bencana alam longsor ataupun banjir. Keberadaan leuweung 'hutan' ini menjamin kebutuhan air bersih selalu tersedia dengan baik saat musim kemarau sekalipun.

Secara umum, pemukiman warga tidak lagi berbentuk rumah tradisional. Walaupun demikian, ada beberapa yang masih mempertahankan ciri-ciri ketradisionalannya. Dan, yang paling mencolok adalah Bumi Ageung yang didiami oleh Abah Acim, kokolot Kampung Cipatat Kolot. Di sebelah depan, agak menjorok ke bawah terdapat sebuah rumah khas Sunda yang terbuat dari bilik dan kayu. Persis di samping kiri Bumi Ageung tersedia sebuah saung lisung. Terpisah oleh sebuah jalan kecil terdapat dua buah leuit yang berada di bagian kanan Bumi Ageung. Kondisi leuit saat ini kurang terawat karena jarang dipergunakan.

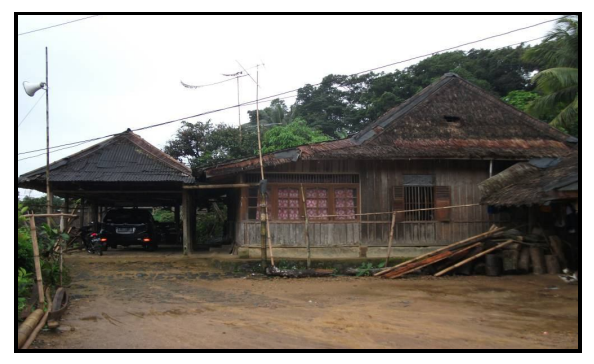

Gambar 7 Halaman samping Bumi Ageung.

Sumber Dokumentasi BPNB Bandung, 2012. 
Bumi Ageung (gambar 7) merupakan sebuah rumah kebesaran dari Kampung Cipatat Kolot dan kerap dipergunakan dalam berbagai acara adat antarkasepuhan wilayah Banten Kidul.

Tata ruang Bumi Ageung terdiri atas tiga bagian, yaitu beranda disebut dengan istilah tepas atau émpér. Kedua adalah bagian tengah rumah yaitu kamar tidur pemilik beserta anggota keluarga. Istilah untuk menyebutkan tengah rumah adalah pangkéng, enggon atau pajuaran. Pada bagian tengah imah juga disediakan sebuah ruang tempat berkumpul keluarga. Ketiga disebut dengan tukang imah yang berfungsi sebagai dapur. Bumi Ageung memiliki dua buah dapur dan sebuah $g o a h^{4}$. Dapur pertama difungsikan untuk memenuhi kebutuhan pangan keluarga sementara dapur kedua khusus dipergunakan apabila ada upacara adat.

Leuit yang berjumlah dua buah secara adat memang harus terpisah dari rumah penduduk. Pengecualian dari Kampung Cipatat Kolot ini lebih diakibatkan oleh penggunaan leuit yang sudah sangat jarang sehingga hanya keluarga Abah Acim saja yang masih mempergunakan leuit tersebut sementara warga lainnya lebih memilih cara lain untuk mengelola hasil panennya.

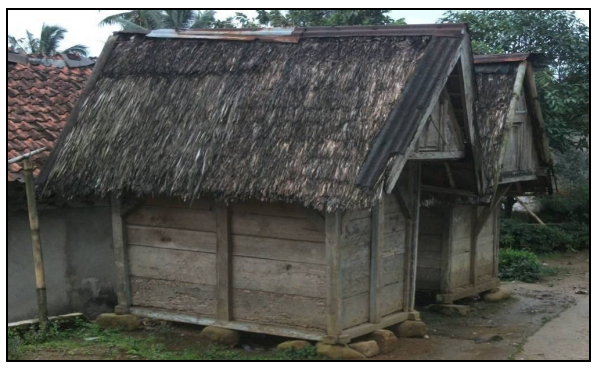

Gambar 8 Dua unit leuit yang berada di bagian belakang Bumi Ageung.

Sumber Dokumentasi BPNB

4 Goah berfungsi untuk menyimpan bahan makanan, bumbu-bumbu masak, beras, perabot-perabot dapur dan padaringan (tempat meyimpan beras).
Bandung, 2012.

Hal serupa juga terjadi pada saung lisung yang sudah mulai ditinggalkan kegunaannya oleh warga Kampung Cipatat Kolot. Hanya keluarga Abah Acim saja yang masih mempertahankan fungsi saung lisung tersebut.

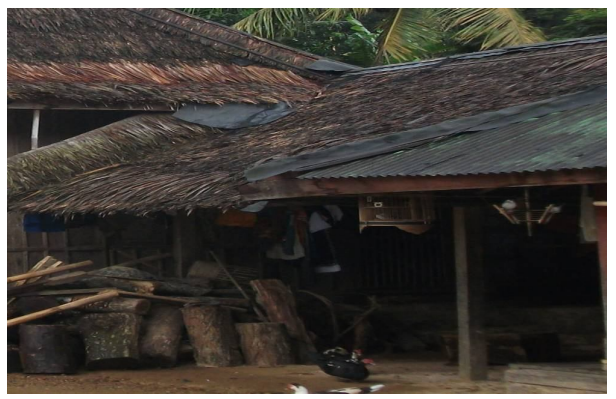

Gambar 9 Saung lisung yang berada di belakang Bumi Ageung.

Sumber Dokumentasi BPNB Bandung, 2012.

Kondisi saung lisung demikian juga leuit kurang terawat. Hal ini disebabkan sudah jarang dipergunakan oleh warga untuk menumbuk padi. Mereka lebih memilih cara modern dengan pertimbangan lebih praktis dan lebih cepat cara kerjanya.

Berdasarkan kondisi Bumi Ageung beserta kelengkapannya yang kini berada "sendirian" di tengah-tengah bangunan "modern" lainnya dapat dikatakan bahwa Kampung Cipatat Kolot memang tengah mengalami dinamika modernisasi di segala bidang. Memang surat yang dikeluarkan Depdikbud perihal penetapan Kampung Cipatat Kolot pada tahun 1988 silam kondisi masyarakat beserta kelengkapan budayanya masih kental dan dapat dikatakan jauh berbeda dengan kondisi saat ini. Namun demikian, patut diperhatikan bahwa Kampung Cipatat Kolot merupakan sosok yang cukup penting bagi Kasepuhan Banten Kidul sehingga penetapan tersebut haruslah tetap dipertahankan dengan cara menata kembali nilai budaya yang ada namun dengan tidak 
mengganggu stabilitas sosial budaya yang telah ada.

\section{PEN UTUP}

Tradisional dan modern pada prinsipnya hanyalah sebuah rentang waktu yang memisahkan antara budaya dahulu dan sekarang. Apabila tidak ada rentang waktu maka kedua budaya tersebut adalah sama-sama menjadi trend (pada masanya). Unsur-unsur tradisi yang hingga saat ini masih ada merupakan bagian - bagian dari masa lalu yang memiliki nilai lebih dan masih dianut oleh kalangan masyarakat yang percaya bahwa nilai lebih tersebut masih memberikan keuntungan baik dari segi fisik maupun nonfisik (batiniah). Proses pemudaran budaya yang saat ini terjadi disebabkan kurangnya proses regenerasi sehingga nilai tradisi yang memiliki kandungan positif sangat tinggi bagi pengembangan akhlak manusia harus punah begitu saja setelah mereka melihat mayoritas daerah lain (kota besar) memiliki style sangat berbeda dengan dirinya baik dari segi materi maupun gaya hidup.

Sama halnya dengan Kampung Cipatat yang saat ini mulai terkena imbas gaya hidup "modern" sudah mulai merasuk semakin jauh ke dalam inti budaya adi luhung yang sebelumnya mereka pegang teguh. Sifat keegoan dan persaingan gaya hidup sudah tampak mulai dari kepemilikan benda modern (handphone, sepeda motor, TV, dan sebagainya) hingga penggunaan lingkungan alam sebagai mata pencaharian tanpa melihat keseimbangan alam yang sebelumnya sangat dijaga oleh nilai dan norma adat.

Proses pemudaran nilai budaya tradisional yang saat ini sedang terjadi pada Kampung Adat Cipatat sebenarnya masih belum sebegitu jauh merambah pada inti budaya mereka selaku urang Sunda. Predikat urang Sunda yang masih melekat pada masyarakat kampung cipatat dapat menjadi "kartu As" yang apabila dikelola dengan baik maka bukan tidak mungkin dapat mengembalikan jati diri urang Sunda sesungguhnya yaitu back to nature atau dalam bahasa sundanya adalah lemah cai.

Perangkat kasundaan masyarakat

Kampung Cipatat Kolot pada masa lalu memang sangat lekat. Mulai dari kesenian tradisional seperti jipeng, wayang golek, jaipongan, dan sebagainya; pembuatan rumah mulai dari rangkay imah, ruangan imah, tengah imah, tukang imah, sampai pada asesoris di sekitarnya yang tidak lepas dari leuit dan saung lisung. Berbagai upacara tradisional mulai dari upacara seputar daur hidup hingga upacara menghormati atau mensyukuri alam. Beberapa aktifitas tersebut di atas menandakan bahwa sangat disayangkan apabila budaya tradisional yang menjadi landasan hidup masyarakat Kampung Cipatat Kolot begitu saja punah dan digantikan dengan budaya "modern" yang penuh persaingan individual tanpa melihat kondisi lingkungan sekitarnya.

Saran yang dapat disampaikan dalam hal ini adalah bahwa diperlukan adanya kajian lebih mendalam mencakup potensi sosial budaya, sumberdaya manusia, dan alam oleh berbagai instansi terkait. Hasil kajian tersebut diharapkan dapat menciptakan solusi yang mampu mempermudah aktifitas masyarakat dalam melakukan kegiatan sosial dan ekonomi tanpa menghilangkan nilai dan karakter budaya masyarakat Kampung Cipatat Kolot yang telah ditetapkan sebagai Kampung Adat.

\section{DAFTAR SUMBER}

\section{Buku}

Bidang Kebudayaan Disbudpar Provinsi Jabar, 2009.

Data Kampung Adat di Jawa Barat, Bandung: Bidang Kebudayaan Disbudpar Provinsi Jabar.

Kartika. 2010.

"Studi Kasus Perubahan Kosa Kata Sunda Kabupaten Bogor". Tesis. Depok: Fakultas Ilmu Pengetahuan Budaya, 
Program Studi Linguistik. Universitas Indonesia.

Koentjaraningrat. 1981.

Pengantar Ilmu Antropologi. Cet. 3. Jakarta: Rineka Cipta.

Koentjaraningrat. tt.

"Antropologi Hukum", dalam Jurnal Antropologi No. 47.

Harwantiyoko, dan Neltje F.Katuuk. tt. Pengantar Sosiologi dan Ilmu Sosial Dasar, Jakarta: Gunadarma

Ihromi, T.O. 1989.

"Beberapa Catatan mengenai Perkembangan Antropologi Hukum sebagai Disiplin Akademik Indonesia", dalam Jurnal Antropologi no. 47.

Nugraheni, Endang dan Adi Winata. 2002. "Kearifan Tradisional Masyarakat Kasepuhan Halimun Ditinjau dari Aspek Kelestarian Lingkungan". Laporan Penelitian. Jakarta: Pusat Studi Indonesia, Lembaga Penelitian-Universitas Terbuka.

Setyaningrum, Ary. 2011.

"Dinamika Kesenian Lenong Betawi 1970-1990”, Skripsi. Depok: Fakultas Ilmu Budaya Program Studi Ilmu Sejarah, Universitas Indonesia.

\section{Internet}

"Ziarah Salembur Kasepuhan Adat Cipatat Kolot Sukajaya Bogor", http://kalakayjasinga.blogspot.com/2009/11/ziarahsalembur-kasepuhan-adat-cipatat.html tanggal 16 Nopember 2009. 